\title{
A revision of Dimeria (Gramineae-Dimeriinae) in Malesia with a note on Cymbachne
}

\author{
J.F. Veldkamp ${ }^{1}$
}

Key words

Cymbachne

history

nomenclature

\begin{abstract}
In Malesia there are 4 species of Dimeria (Gramineae). A brief history of the genus with a key, nomenclature, descriptions, and notes is provided. Dimeria ciliata, $D$. dipteros, and $D$. fuscescens are reduced to $D$. chloridiformis, $D$. leptorhachis and its var. velutina to $D$. gracilis, $D$. monostachya to $D$. kurzii. Dimeria ornithopoda var. gracillima is not recognised. Cymbachne is doubtfully referred to Ischaemum.
\end{abstract}

Published on 16 November 2016

\section{INTRODUCTION}

Dimeria R.Br. (Gramineae) is a genus with about 67 species ranging from Madagascar, India to S Korea, Marianas, and Australia. The majority (c. 34 species) occur in Peninsular India (Hackel 1889, Hooker 1896, Bor 1953, Kiran Raj 2008) indicating it to be the centre of speciation of the subtribe Dimeriinae Hack. In SE Asia, approximately 14 have been reported for Indo-China, Malesia, China, and the Pacific (Camus \& Camus 1922, Ridley 1925, Jansen 1953, Schmid 1958, Henty 1969, Gilliland 1971, Lazarides 1980, Chen \& Phillips 2006, Clayton \& Snow 2010, Teerawatananon et al. 2014). In Australia there are 3 (Simon 1993) and in the Pacific (Clayton \& Snow 2010) 3. Although rather anomalous, it clearly belongs to the Andropogoneae Dumort. It is immediately distinct by the tenacious, espatheate, solitary or digitate racemes with solitary hermaphrodite spikelets lateral to the rachis, shortly pedicelled, laterally compressed, and florets with 2 anthers (there are some reports of 3 , but this has not been seen in this study). The authorship of the subtribe Dimeriinae is sometimes given as C.E. Hubbard (1934), but he explicitly cited Hackel (1889).

It was first described from Australia with as the only species $D$. acinaciformis $\mathrm{R}$. Br. which Brown placed between Imperata Cirillo and Ischaemum L. He also mentioned an unnamed species from India. The name alludes to the paired racemes

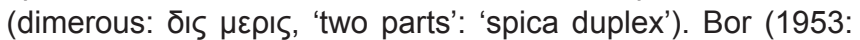
554) has suggested that Brown had inspected an abnormal specimen with 3 anthers.

It was not the first species known to Western science, though, for Anthoxanthum avenaceum Retz. was described in 1783 from South India, now known as $D$. avenacea (Retz.) C.E.C.Fisch. Haplachne J.Presl (1830) was based on H. pilosissima J.Presl from Luzon, the Philippines, a synonym of $D$. chloridiformis (Gaudich.) K.Schum. \& Lauterb. The name means 'simple chaff'

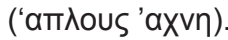

Didactylon Zoll. \& Moritzi (1846) was described with two species from Java, both forms of Dimeria ornithopoda Trin. The

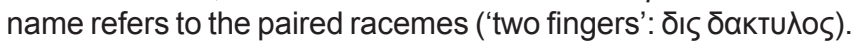
Psilostachys Steud. (1854: 413; non Turcz. 1843, Euphorbiaceae, nec Hochst. 1844, Amaranthaceae) with P. hohenackeri

\footnotetext{
${ }^{1}$ Naturalis Biodiversity Center, section Botany, P.O. Box 9517, 2300 RA Leiden, The Netherlands; jef.veldkamp@naturalis.nl.
}

Steud. was described from Canara (Karnataka) in S India. This is now $D$. hohenackeri (Steud.) Hochst. ex Miq. The name

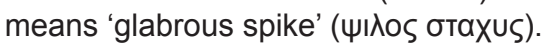

Next to this Steudel (1854) recognised 6 species in Dimeria.

Pterygostachyum Steud. (1854: 413) was based on P. lehmanii Nees ex Steud. from India, now $D$. lehmannii (Nees ex Steud.) Hack. The name means 'winged spike' (птерuүо б бтахчऽ).

Hackel (1889) recognised 12 species, 2 subspecies, and 10 varieties.

Woodrowia Stapf (1896) from India was described in the Agrostideae Dumort. and compared to Garnotia Brongn. It was dedicated to George Marshall Woodrow (1846-1911; see Stapf 1895, Desmond 1977), the collector of the type of W. diandra Stapf (non D. diandra Griff. 1851a, b), now D. stapfiana C.E.Hubb. ex Pilg.

The genus was revised for India by Bor (1953) with 25 species and more recently Kiran Raj (2008) treated the subtribe with 2 genera and 43 taxa in an unpublished thesis.

For the Malesian taxa the diagnostic characters are but few; hence several are here reduced.

For the record it may be noted that Roberty (1960) had a single species, $D$. avenacea (Retz.) C.E.C.Fisch., with 22 subvarieties in a monotypic 'Cohors' Dimeriastreae Roberty. He erroneously cited the Indian endemics $D$. bialata C.E.C.Fisch. and $D$. fischeri Bor for Malesia.

\section{TAXONOMIC POSITION}

The Dimeriinae generally have been regarded as a member of the Andropogoneae Dumort. with Dimeria as the only genus, until Nanooravia Kiran Raj \& Sivad. (in Kiran Raj et al. 2013a, b) with one species from India was described. Affinities have been pointed out with e.g. Ischaemum L., Saccharum L., and Sorghum Moench. Clayton \& Renvoize (1986) regarded it as derived from the Ischaeminae J.Presl by suppression of the sessile spikelet, as the remaining spikelets are shortly pedicelled. This might as well be a loss of the pedicelled ones, as was observed by Miquel (1851; 'rudimentary pedicels'), but by no one else. In the Andropogoneae reduction of the pedicelled spikelet is the usual trend, while the 'sessile' spikelets sometimes may be shortly pedicelled. The reduction of the pedicelled spikelets usually is from male, neuter, to absent. 


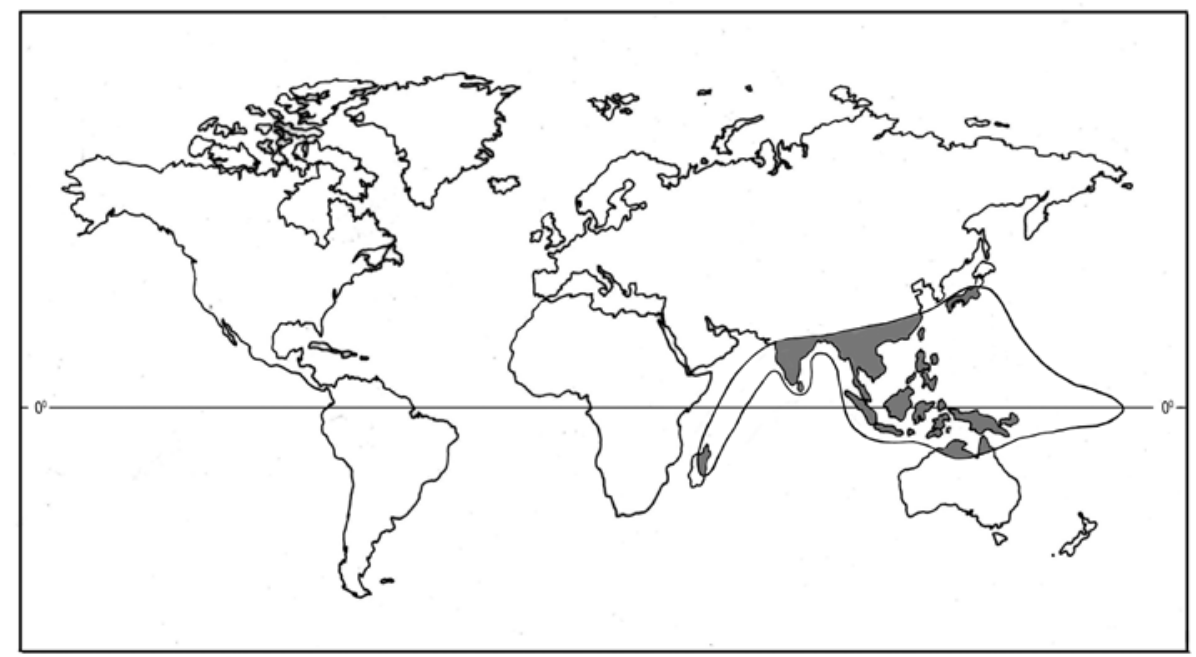

Map 1 Distribution of the Dimeriinae (by Kiran Raj with kind permission).

Kellogg \& Watson (1993: 296) in a phylogenetic analysis based on morphological data treated Dimeria as a sister group of Cleistachne Benth. of the subtribe Sorghinae Bluff et al. with both genera nesting in a Saccharinae clade. Estep et al. (2014) in a nuclear molecular study, however, found Dimeria nested in a clade within Ischaemum, but with little basal support, so a reduction of Dimeria to Ischaemum seems premature. Morphologically the two are very dissimilar.

Teerawatananon et al. (2011a, 2014) regarded the Dimeriinae as monophyletic and most related to Eulalia Kunth s.l. and Ischaemum. Kellogg (2015) actually reduced the Dimeriinae to Ischaeminae, but remarked "The subtribe lacks obvious morphological synapomorphies, though the lower glume often has a winged keel". The latter feature is highly variable in both genera. However, she also pointed out the presence of "leaf epidermis with intercostal cells with several papillae per cell". Whether this is indeed a synapomorphy remains to be seen.

\section{Sections}

Bor (1953) recognised three sections in India: Annulares Bor (type: D. woodrowii Stapf), Capillares Bor (D. hohenackeri Hochst. ex Miq.), and Loriformes Bor (D. pubescens Hack.), but did not account for $D$. acinaciformis, as this is an endemic of Australia, and would be the type of the autonym. Kiran Raj et al. (2015) recognised for India four sections with 12 species in sect. Dimeria, some of which had been placed by Bor in the Capillares and Loriformes.

In Malesia there are:

- Dimeria: D. chloridiformis, D. dipteros Reeder, D. gracilis Nees ex Steud., D. monostachya Reeder, D. ornithopoda. - Loriformes: D. kurzii Hook.f.

\section{Dimeria - Map 1}

Dimeria R.Br. (1810) 204; Bor (1953) 553; Teerawat. et al. (2014) 137. Type: Dimeria acinaciformis R.Br.

Haplachne J.Presl (1830) 234. - Dimeria R.Br. [sect.] Haplachne (J.Presl) Endl. (1836) 106. - Type: Haplachne pilosissima J.Presl [= Dimeria chloridiformis (Gaudich.) K.Schum. \& Lauterb.].

Didactylon Zoll. \& Moritzi in Moritzi (1846) 99. — Lectotype: Didactylon simplex Zoll. \& Moritzi (= Dimeria ornithopoda Trin.), designated by Clayton \& Renvoize (1986: 349).

Annual or perennial, caespitose. Culms internodes hollow. Leaf blades linear. Ligules truncate, margin lacerate or fimbriate. Inflorescences determinate, espatheate, composed of 1-14 digitate racemes. Spikelets numerous, hermaphrodite, solitary, lateral to and partially embedded in the rachis, secund, biseri- ate, pedicellate, laterally compressed. Glumes more or less equal, awnless, carinate, 1-3-nerved. Lower floret epaleate, sterile, lemma awnless, 0-nerved, similar in texture to the upper one; upper lemma incised, awnless to awned from the sinus, glabrous, 1-3-nerved. Lodicules absent or very small. Stamens 2, rarely 3 (see note). Styles fused, stigmas 2. Hilum punctiform, embryo large. $x=7,25$.

Distribution - C. 67 species from Madagascar to S Korea, Micronesia and northern Australia. In Malesia 4 species.

Note - Brown (1810) described the type species $D$. acinaciformis with three stamens, other authors (e.g. Hackel 1889: 86 'certissime') have reported two. Presl (1830) said two, his artist depicted three. Kiran Raj erroneously (fide litt.) reported the presence of 3 stamens in D. thwaitesii Hack.

\section{KEY TO THE TAXA}

1. Racemes 2 or more. (Rarely 1 in D. chloridiformis, then plants perennial; culms $0.3-1 \mathrm{~m}$ long; racemes rachis flattened to triquetrous, internodes $0.8-1.5 \mathrm{~mm}$ long; lower glumes keel puberulous to pilose (30 x!); upper glumes acute to mucronate, keel pilose $(30 \mathrm{x} !) \ldots \ldots \ldots \ldots \ldots$

1. Racemes 1. - Annuals. Racemes rachis flattened, 0.4-0.9 $\mathrm{mm}$ wide. Spikelets $4.5-8 \mathrm{~mm}$ long. Glume keels not winged. Anthers $0.5-1.5 \mathrm{~mm}$ long. Malay Penins. (Kedah), Papua New Guinea ... . . . . . . . . . . . 3. D. kurzii

2. Perennials. - Spikelets $3.3-8 \mathrm{~mm}$ long . . . . . . . . 3

2. Annuals. - Racemes rachis $0.1-0.4 \mathrm{~mm}$ wide. Spikelets $1-$ 3.5(-4.5) mm long. Glume keels not winged. Anthers 0.25$0.8 \mathrm{~mm}$ long. Widespread ... . . . . . 4. D. ornithopoda

3. Racemes rachis flattened, or triquetrous. Upper glumes keel

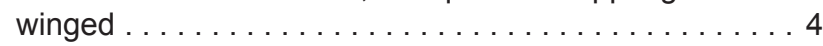

3. Racemes rachis filiform, terete. Upper glumes keel not winged. - Malay Pen. (Kedah). . . . . . . . . 2. D. gracilis

4. Upper glumes keel pilose (30 $\mathrm{x}$ !), wing absent to narrow, not rugose. - Philippines (Palawan), New Guinea.........

$\ldots \ldots \ldots \ldots \ldots \ldots \ldots \ldots$. D. chloridiformis

4. Upper glumes keel ciliolate $(30 \mathrm{x}$ !), wing broad, rugose. Thailand ..................... kerrii

\section{Dimeria chloridiformis (Gaudich.) K.Schum. \& Lauterb.}

Dimeria chloridiformis (Gaudich.) K.Schum. \& Lauterb. (1900) 165. - Andropogon chloridiformis Gaudich. (1826) 72, 75 (nomen); (1829) 412 (descr.). - [Dimeria avenacea (Retz.) C.E.C.Fisch. subvar. chloridiformis (Gaudich.) Roberty (1960) 398, 402, nom. inval.]. - Type: Gaudichaud s.n. (holo P; photo in $\mathrm{BRI}, \mathrm{K})$. 
Haplachne pilosissima J.Presl (1830) 235, t. 38. - Diplachne pilosissima (J.Presl) Trin. (1832) 336. - Type: Haenke s.n. (holo PR; photo BISH).

Dimeria fuscescens Trin. (1832) 335. - [Dimeria avenacea (Retz.) C.E.C. Fisch. subvar. fuscescens (Trin.) Roberty (1960) 398, 401, nom. inval.]. - Type: Wallich 8841 ex Lindley in Herb. Trinius 1253.1 (LE, microfiche IDC BT-16/1; G, K, Herb. Wallich, microfiche IDC 7394; W).

Dimeria ciliata Merr. (1914) 262. - [Dimeria avenacea (Retz.) C.E.C.Fisch. subvar. ciliata (Merr.) Roberty (1960) 398, 402, nom. inval.]. - Type: BS 9320 (Merrill) (PNH lost; BISH, photo in BRI, G, K; ? L, NSW).

Dimeria ciliata Merr. var. heteromorpha Reeder (1948) 325. - Type: Brass 7807 (holo A; BISH, BO 1864466, L, US).

Dimeria dipteros Reeder (1948) 324, t. 6. - Type: Brass 11738 (holo US; A, BO, L)

Dimeria falcata auct. non Hack.

Eulalia argentea Brongn. var. queenslandica auct. non Hitchc.: Hitchc. (1936) 126.

Perennials. Culms $0.3-1 \mathrm{~m}$ long. Nodes bearded. Ligules $0.5-1 \mathrm{~mm}$ long, margin glabrous (30 x!) or ciliolate (30 x!). Leaf blades $3-25 \mathrm{~cm}$ by $2-5(-8) \mathrm{mm}$, puberulous or pilose, sometimes glabrous. Racemes $1-6$, rachis flattened, $4-15 \mathrm{~cm}$ long, 0.2-1 $\mathrm{mm}$ wide, internodes $0.8-4 \mathrm{~mm}$ long, margin glabrous, ciliate, or pilose $(30 \mathrm{x}$ !). Pedicels $0.3-1 \mathrm{~mm}$ long. Spikelets $3.3-4.8(-5.6) \mathrm{mm}$ long. Callus hairs $0.2-1 \mathrm{~mm}$ long. Lower glumes keel puberulous to pilose (30 $\mathrm{x}$ !), apex acuminate to mucronate, mucro 0-0.2 mm long, not winged; upper glumes acute to mucronate, mucro $0-0.6 \mathrm{~mm}$ long, keel winged or not, pilose (30 x!), wing narrow, not rugose. Awns 4-17 mm long, incl. 0-3.5 mm long column. Anthers $0.8-3.5 \mathrm{~mm}$ long. $2 \mathrm{n}=50$.

Distribution - Sri Lanka, Nepal, India (Andhra Pradesh, Assam, Bengal, Kerala, Manipur, Meghalaya, Nagaland, Orissa, Tamil Nadu) to Thailand (NE: Loei; E: Chayaphum; Pen.: Satun; therefore may be expected in N Malay Pen.), N Vietnam, Micronesia (Guam, Yap), Australia (N Territory, Queensland); Malesia: Philippines (Palawan), New Guinea: Irian Jaya (Baliem River); Papua New Guinea (Central, W-, S Highlands, Western Prov.).

Habitat - Savannahs, sometimes dominant, swampy places, wet rocks, open pine or evergreen forest; 30-2530 m altitude.

Collector's notes - Erect, fairly densely tufted, culms 30$100 \mathrm{~cm}$, purple. Leaves dull mid green, bluish green with silver hairs. Inflorescence yellow/green, purplish. Spikes 1-2. Anthers yellow. Style white, pale yellow.

Notes - The var. heteromorpha is merely a rather glabrous form with an extended wing on the upper glume.

An isotype in A of Dimeria dipteros is a small specimen, but with cataphylls and extra-vaginal branching, hence not an annual. There were hardly discernible wings on the glumes. Hence the species is reduced here.

The Continental Asian representatives are known as $D$. fuscescens Trin. (1832) but I have failed to find any convincing differences.

Roberty (1960: 402) cited his subvar. ciliata for Deccan (India) and the Philippines. The first surely is a misidentification.

Reeder (1948: 325) and Jansen (1953: 267) noted that the peduncle would be "short pubescent below the inflorescence". I have not seen this.

The development of a wing on the keel of the upper glume is apparently not such a reliable character as some keys suggest. Merrill (1914) did not note the upper glume to be winged, Reeder said prominently in upper part. Actually it may be absent to broad, while the plants in other respects do not seem to differ.

Although said to be common in e.g. New Guinea (Henty 1969: 80 ), only two specimens were received from K. Possible specimens in $L$ could not be found.

\section{Dimeria gracilis Nees ex Steud.}

Dimeria gracilis Nees ex Steud. (1854) 413. - [Dimeria avenacea (Retz.) C.E.C.Fisch. subvar. gracilis (Nees ex Steud.) Roberty (1960) 398, 402 , nom. inval.]. - Type: Macrae 229 in Herb. Lindley (holo P; CGE).

Dimeria laxiuscula Thwaites ex Trimen (1885) 272. - Type: CP 3863 (Thwaites) (holo PDA; BO, K, P).

Dimeria leptorhachis Hack. (1889) 90 (incl. subsp. genuina Hack., nom. inval.). - [Dimeria avenacea (Retz.) C.E.C.Fisch. subvar. leptorhachis (Hack.) Roberty (1960) 398, nom. inval.]. — Lectotype: CP 24 (Thwaites) (W 18890058700; iso G, K, PDA), designated by Roberty (1960: 398).

Dimeria leptorhachis Hack. subsp. velutina Hack. (1889) 90. — Dimeria velutina (Hack.) Bor (1952 '1951') 458. - [Dimeria avenacea (Retz.) C.E.C. Fisch. subvar. velutina (Hack.) Roberty (1960) 399, 402, nom. inval.]. Lectotype: Griffith 6799 (K 000245776 ; iso G, W 1916-0034768), designated by Teerawatananon et al. (2014: 145).

Perennials. Culms $0.45-1.4 \mathrm{~m}$ long. Nodes glabrous, puberulous, or bearded. Ligules $0.3-2 \mathrm{~mm}$ long, margin ciliolate (30 $\mathrm{x}$ !). Leaf blades $15-25 \mathrm{~cm}$ by $2-12 \mathrm{~mm}$, glabrous or pilose. Racemes 3-11, rachis filiform, terete, $4-20 \mathrm{~cm}$ long, $0.2-0.5$ $\mathrm{mm}$ wide, internodes $2-4 \mathrm{~mm}$ long, margin glabrous (30 $\mathrm{x} !)$, smooth (30 $\mathrm{x}$ !). Pedicels $0.5-2.5 \mathrm{~mm}$ long. Spikelets $4.5-8$ $\mathrm{mm}$ long. Callus hairs $0.5-1 \mathrm{~mm}$ long. Lower glumes keel scaberulous (30 $\mathrm{x}$ !) or pilose (30 x!), apex obtuse to mucronate, mucro 0-0.8 mm long, winged or not; upper glumes acuminate to mucronate, mucro $0-0.5 \mathrm{~mm}$ long, keel winged or not, pilose (30 x!), narrow, not rugose. Awns 5-14 mm long, incl. 2.5-4 $\mathrm{mm}$ long column. Anthers 2-3.5 mm long.

Distribution - Sri Lanka, W India (Goa, Karnataka, Maharasthra), Burma (Tenasserim), Thailand (Trat), Cambodia (Kampong Speu), Vietnam (Dalat), Malesia: Malay Pen. (Kedah).

Habitat — On scrub, grass land, pine and dipterocarp forest, 600-975 $\mathrm{m}$ altitude.

Notes - The differences between $D$. leptorhachis and its var. velutina is only in the pubescence of the sheaths and leaves, which is insufficient to recognise these forms at any level. The differences with $D$. gracilis were equally unimportant.

Collected in the same site in Kedah, G. Jerai, were Burkill 3304 (L, SING) and KLU 8157 (Kassim \& Carrick) (KLU).

Distribution remarkable, everywhere apparently very local.

\section{Dimeria kurzii Hook.f.}

Dimeria kurzii Hook.f. (1896) 103. - [Dimeria avenacea (Retz.) C.E.C.Fisch. subvar. kurzii (Hook.f.) Roberty (1960) 398, 401, nom. inval.]. — Lectotype: Kurz 2741 (K 000245781; iso G, K 000245780), designated by Teerawatananon et al. (2014: 141).

Dimeria sinensis Rendle (1904) 359. - Lectotype: Hance 1385, p.p. ('Guangzhou') (BM $000959790 \equiv-91,-92$, the largest left hand culm), designated (first step) by Teerawatananon et al. (2014: 145), designated here (second step).

Dimeria monostachya Reeder (1948) 324, t. 5, f. a, b. — Type: Brass 7806 (holo A; BISH, BO, ?K, ?L, US).

Dimeria falcata auct. non Hack: Chase (1939) 313

Annuals. Culms 0.1-0.6 m long. Nodes puberulous or bearded. Ligules $0.4-1 \mathrm{~mm}$ long, margin ciliolate $(30 \mathrm{x} !)$. Leaf blades $1.3-10 \mathrm{~cm}$ by $1-5 \mathrm{~mm}$, pilose. Racemes 1 , rachis flattened, $1.6-7 \mathrm{~cm}$ long, $0.4-0.9 \mathrm{~mm}$ wide, internodes $0.2-1.5 \mathrm{~mm}$ long, margin pilose $(30 \mathrm{x} !)$. Pedicels $0.2-0.7 \mathrm{~mm}$ long. Spikelets $2-4 \mathrm{~mm}$ long. Callus hairs $0.2-0.4 \mathrm{~mm}$ long. Lower glumes keel pilose (30 $\mathrm{x}$ !), apex acute to acuminate, not winged; upper glumes acuminate, keel not winged to winged, keel pilose (30 $\mathrm{x} !)$, wing narrow, not rugose. Awns (6-)9-18 mm long, incl. the (1-)2-6 mm long column. Anthers 0.5-1.5 mm long.

Distribution - India (Kerala), disjunct with Burma (Bago, Kachin, Shan, Taninthayi), Thailand (Eastern: Buri Ram, Nakhon Ratchasima, Ubon Ratchathani; Southeastern: Chantaburi; Central: Nakhon Nayok; Penins.: Phangnga, Ranong, Satun, Songkhla), Cambodia (Stung Treng), Vietnam, S China; 
Malesia: Malay Penins. (Kedah), Papua New Guinea (Western Prov.).

Habitat - Lateritic, sandy soil, dry deciduous forest, savannahs, disturbed places, edge of rice field, beaches, locally abundant, 0-1200 m altitude.

Collector's notes - Annual. Culms violet. Blades green above, pale green underneath. Inflorescence axes greenish. Glumes green, pinkish purple, violet. Awns tan, violet.

Notes - Reeder compared his $D$. monostachya to $D$. sinensis Rendle, a synonym of $D$. kurzii. The only difference outside the very disjunct distribution is that the awns are shorter than in $D$. kurzii. The isotype specimen in A does not have broadly winged upper glumes, as described. I have seen specimens with such short awns also from Vietnam (e.g. Schmid s.n. 3 Feb. 1954; P):

-. Awns 9-18 mm long, incl. 2-6 mm long column D. kurzii

-. Awns 6-8.5 mm long, incl. 1-2 mm long column . . . . . .

D. monostachya

Teerawatananon et al. (2014: 138) differentiated between $D$. kurzii and $D$. sinensis by the absence or presence of a wing on the keel of the upper glume. Having studied some specimens of both species identified by them, I fail to find this difference (or any other). Indeed some of their ' $D$. sinensis' are completely wingless.

Hance 1385 is the number of a species, which consists of several collections, most pertaining to $D$. falcata Hack. as was already pointed out by Rendle (1904). The lectotypification of D. sinensis was sorted out by Teerawatananon et al. (2014), but unfortunately without 'designated here'.

\section{Dimeria ornithopoda Trin.}

Dimeria ornithopoda Trin. (ante 24 Jan. 1820) 167, t. 14; Ridl. (1903) 274 ('D. ornithopodioides', sphalm.); Honda (1930) 324 [incl. forma typica Hack. ex Honda, nom. inval.]; Bor (1953) 572 (incl. var. genuina, nom. inval.). [Dimeria avenacea (Retz.) C.E.C.Fisch. subvar. ornithopoda (Trin.) Roberty (1960) 399, 401, nom. inval.]. - Type: Herb. Trinius 1254.1 (holo LE, IDC microfiche BT-16/1).

Dimeria tenera Trin. (1832) 335. - Dimeria ornithopoda Trin. var. tenera (Trin.) Hack. (1889) 81. - Dimeria ornithopoda Trin. [var. tenera Hack.] subvar. typica Hack. (1889) 81, nom. inval. - [Dimeria avenacea (Retz.) C.E.C.Fisch. subvar. tenera (Trin.) Roberty (1960) 399, 402, nom. inval.]. Lectotype: Chamisso s.n. (LE Herb. Trinius 1255.1, IDC microfiche BT-16/1; iso B, extant?), designated by Teerawatananon et al. (2014: 142).

Didactylon ramosum Zoll. \& Moritzi (1846) 100; Buse (1854) preprint: 27; (print) 367; Miq. (1857) 479. - Dimeria ornithopoda Trin. var. ramosa (Zoll. \& Moritzi) Hack. (1889) 82; Ridl. (1891) 27 ('subramosa'). — Dimeria ornithopoda Trin. [var. ramosa] subvar. typica Hack. (1889) 82, nom. inval. - Dimeria avenacea (Retz.) C.E.C.Fisch. subvar. ramosa (Zoll. \& Moritzi) Roberty (1960) 399, 402, nom. inval.]. - Type: Zollinger 351 (holo G; K, $\mathrm{L}, \mathrm{U}, \mathrm{W})$.

Didactylon simplex Zoll. \& Moritzi (1846) 100; Miq. (1857) 480. - Type: Zollinger 1595 (holo P; U).

Dimeria glabriuscula F.M.Bailey (1890) 83. - Type: Bailey 23 (holo BRI; MEL). Dimeria ornithopoda Trin. subvar. imperfecta Hack. (1889) 82. - Type: Lobb s.n. (holo G).

Dimeria glabra Ridl. (1925) 192. — Dimeria ornithopoda Trin. var. glabra (Ridl.) Jansen (1953) 266. - [Dimeria avenacea (Retz.) C.E.C.Fisch. subvar. glabra (Ridl.) Roberty (1960) 398, 400, nom. inval.]. - Type: SF 4674 (Burkill) (holo SING; G, K)

Dimeria ornithopoda Trin var. gracillima Bor (1953) 576. — Lectotype: Clarke 21084-B (K 000245790), designated by Teerawatananon et al. (2014: 143).

Annuals. Culms 0.035-0.45(-0.8) m long. Nodes bearded to glabrous. Ligules $0.2-0.5(-1) \mathrm{mm}$ long, margin glabrous, ciliolate, or fimbriate. Leaf blades $1-10(-13) \mathrm{cm}$ by $0.75-3.25 \mathrm{~mm}$, glabrous or sparsely setose. Racemes usually 2 , sometimes 3 , rarely 4 , rachis filiform, terete or triquetrous, $0.7-7(-8) \mathrm{cm}$ long, $0.1-0.5 \mathrm{~mm}$ wide, internodes $1-2 \mathrm{~mm}$ long, margin scaberulous or ciliate $(30 \mathrm{x}$ !). Pedicels $0.1-0.3 \mathrm{~mm}$ long. Spikelets $1-3(-4.5) \mathrm{mm}$ long. Callus hairs $0-0.8 \mathrm{~mm}$ long. Glume keels not winged. Upper glumes acute, smooth, scabrous, ciliolate, or setose. Awn present or absent, (0-)4-6.5(-10) mm long, incl. $1-3.5 \mathrm{~mm}$ long column. Anthers $0.25-0.8 \mathrm{~mm}$ long. $2 \mathrm{n}=14,32$.

Distribution — India to Japan, N Australia, Malesia: throughout.

Habitat - Sunny, infertile soil, grass fields, road sides, river banks, abandoned rice fields in the dry season, resistant to mowing and grazing, locally abundant, 0-1800 m altitude.

Vernacular name - Bird's foot grass.

Collector's notes - Rhizomatous [?]. Culms prostrate, geniculate. Rachis white, margins green. Spikelets purple. Glumes with green veins, sometimes purple tinged. Column purplish brown. Anthers white, yellow. Stigmas white.

Notes - This species is rather variable and Hackel (1889) optimistically and based on only a few specimens distinguished 6 varieties and 4 subvarieties, warning that intermediary forms occur. Bor $(1953,1960)$ for India distinguished four. Jansen (1953) for Malesia provisionally distinguished three. Duistermaat (2005) regarded them as extremes of a range and I agree.

Specimens with spikelets $1-1.5 \mathrm{~mm}$ long and anthers up to $0.25 \mathrm{~mm}$ have been distinguished as var. gracillima Bor (1953: 576), and e.g. Teerawatananon et al. (2014: 143, lectotype!), but otherwise they cannot be distinguished. Some collections appear to be just dwarfed forms.

Forms without awns or mucronate ones (var. glabra) occur within the same population (see also Ohwi 1965, Duistermaat 2005), but I have not seen mixed collections. BS 336719 (Ramos \& Edaño) (SING) from Luzon had spikelets without awns or with short, simple, filiform ones in the same racemes.

\section{POSSIBLE MALESIAN TAXA}

Dimeria avenacea (Retz.) C.E.C.Fisch. forma latilanceifolia Roberty (1960) 398, 400, is a nom. inval., vouchered by Merrill 3226 (G, where it could not be found), Philippines, Luzon, Bataan (n.v.).

Dimeria kerrii C.E.Hubb. ex Teerawat. \& Sungkaew (in Teerawatananon et al. 2011b) 151, t. 2. - Type: Kerr 13868 (holo $\mathrm{K} ; \mathrm{BK}, \mathrm{BM})$.

Description after Teerawatananon et al. (2011b, 2014).

Perennials. Culms up to $1.2 \mathrm{~m}$ long. Nodes bearded. Ligules c. $0.6 \mathrm{~mm}$ long, margin ciliate. Leaf blades $10-20 \mathrm{~cm}$ by 3-4.5 $\mathrm{mm}$, hairy. Racemes $2-3$, rachis flattened, $8-16 \mathrm{~cm}$ long, $0.6-0.7 \mathrm{~mm}$ wide, internodes $1.5-2 \mathrm{~mm}$ long, margin ciliate. Pedicels $0.8-1.2 \mathrm{~mm}$ long. Spikelets $5-6 \mathrm{~mm}$ long. Callus hairs up to $0.5 \mathrm{~mm}$ long. Lower glumes keels not winged; upper glumes acute to acuminate, keel winged, ciliolate, broad, rugose. Awns $12-15 \mathrm{~mm}$ long, incl. $2-3 \mathrm{~mm}$ long column. Anthers $1.8-2 \mathrm{~mm}$ long.

Distribution - Thailand (Peninsula: Satun) and so may be expected in the N Malay Peninsula.

Habitat - Grasslands, moist savannah, c. 50 m altitude.

\section{OTHER SPECIES}

Dimeria fischeri Bor (1953) 564. - Type: Fischer 133 (holo K).

Note - Roberty (1960: 398) recorded it as present in Malesia; the actual distribution is S India (Kerala, Tamil Nadu).

Dimeria scrobiculata C.B.Clarke ex Koord. (1911) 102. Lectotype: Ottolander 358 (BO), designated here.

= Arthraxon hispidus (Thunb.) Makino var. hispidus. 


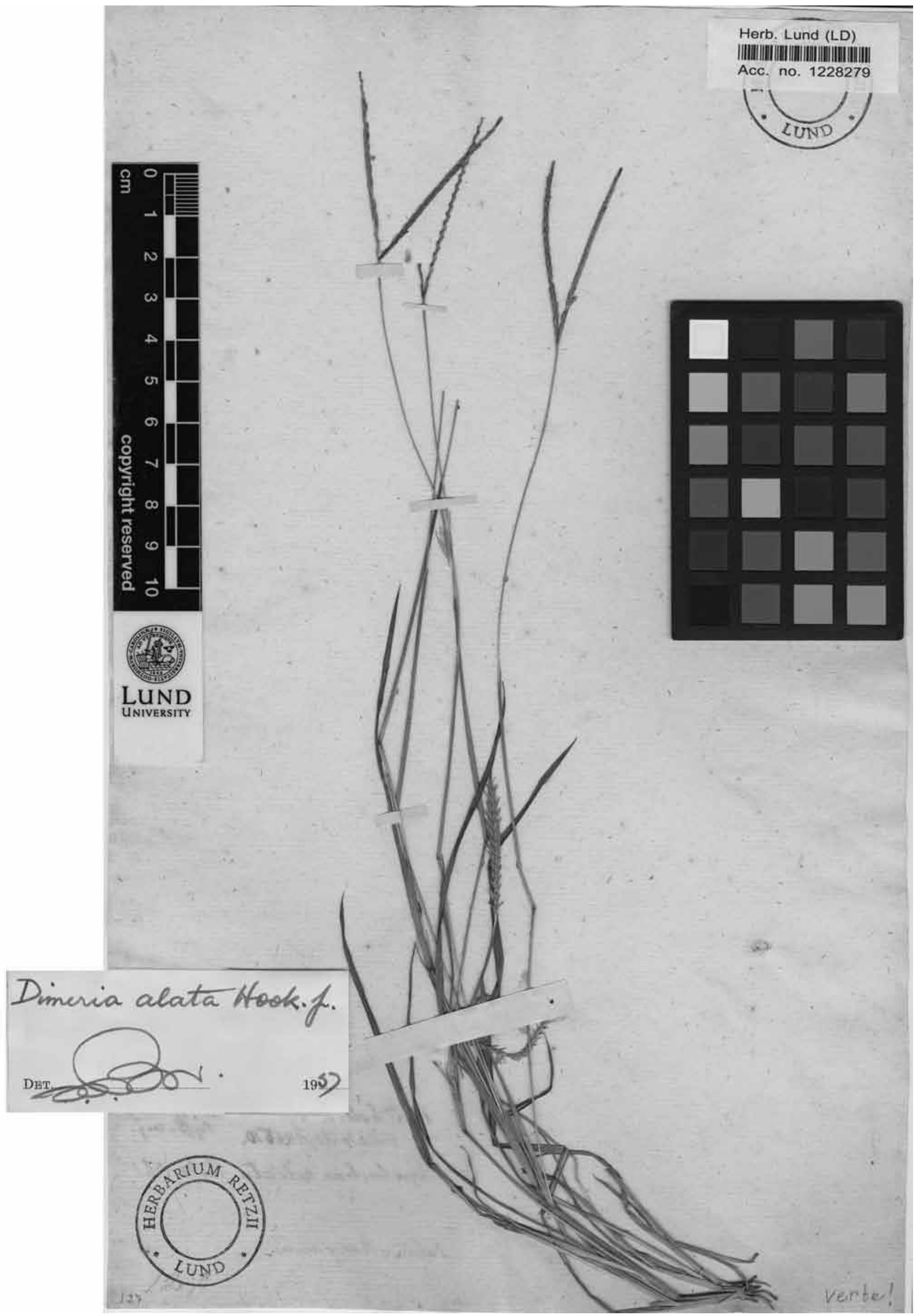

Fig. 1 The Zetterstedt sheet in Lund (1228279). 


\section{Cymbachne}

Cymbachne Retz. (1791) was described with as the single species $C$. ciliata represented by a single (!) specimen collected by König in Bengal. Retzius material may be expected to be in Lund (LD), but it has been long lost. It was not found by Fischer (1932), but as noted by Bor (1960: 139) a specimen is present in the Zetterstedt herbarium (LD 1228279). It was annotated not by Retzius, but by Zetterstedt (Messrs. P. Frodén and P. Lassen, LD, in litt.). Bor identified it as $D$. alata Hook.f., a Sri Lanka endemic (Fig. 1, 2).

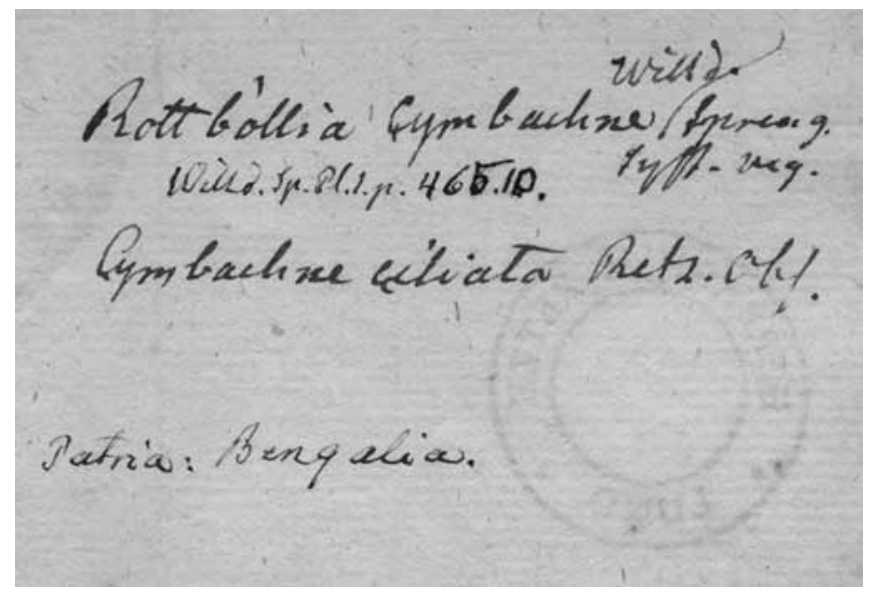

Fig. 2 The Zetterstedt label in Lund (1228279).

However, this cannot be original material. From the reference to Sprengel (1824) on the label and the absence of any mention of König it would seem that after 1824 Zetterstedt tried to identify a collection, and besides the incongruence with the original description, this cannot be the type of $C$. ciliata. That it came from Bengal, as is noted on the label, might well have been a deduction from the provenance cited by Retzius and subsequent authors.

Bor wrote "the description might easily apply to a species of Dimeria ... no need for a change of name". However, the description mentions the presence of paired spikelets, whereby it can never refer to Dimeria R.Br. (1810), which is one of the few andropogonoid genera characterised by solitary ones. Dimeria spikelets have only 2 stamens, 3 are described here, and depicted by Presl (1830; but described as two!). This is most fortunate, as Cymbachne has priority over Dimeria, and there is now no need for a proposal for conservation to prevent about 70 new combinations.

Probably following Bor, Clayton \& Renvoize (1986: 376) have suggested that it was based on a damaged specimen of Dimeria $\mathrm{R} . \mathrm{Br}$. and thus it is perpetuated in the literature.

Willdenow (1797) unseen and without argumentation transferred it to Rottboellia L.f. as R. cymbachne, a superfluous name, as at the time there was no $R$. ciliata. There is no duplicate in the Willdenow herbarium (B). This combination, without any further reference, was used by Steudel (1854: 362).

Hackel (1889: 450) stated to have seen a specimen collected by König in Copenhagen (C), labelled as Cymbachne ciliata. He observed (my translation) that "the description is quite obscure and by no means without errors, for what he calls the female flowers seem to be nothing else than thick pedicels, remaining after de male spikelets have fallen off. Besides what else Retzius adds, agree well with the Koenig specimen and I do not doubt that I have described the same as Retzius' plant. A specimen in the herbarium Retzius, now in Lund, is to be wished for".

In $C$ there are two (!) sheets, which makes them suspect, because a single sheet was expected in Lund:
- C10016736 with 'Rottboellia cymbachne Willd.?' and a label by Hackel: Andropogon cymbachne Hack., and on the back annotated as part of the Herbarium Vahl, and with the names Andropogon cymbachne and Cymbachne ciliata Retzii (K neg. 19385) and 'Konig' (Fig. 3).

HB. VAHLIAN,

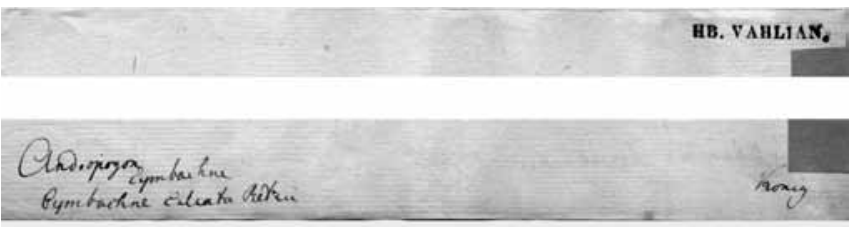

Fig. 3 Backside of C 10016736

- C10016737 with a label by Hackel 'Andropogon cymbachne Hack. / Cymbachne ciliaris Retz.' and a reference to Hofman Dory (??) (K neg. 19384). The 'Rottboellia' in pencil is to be neglected. A note by Clayton states "does not match description" (Fig. 4).

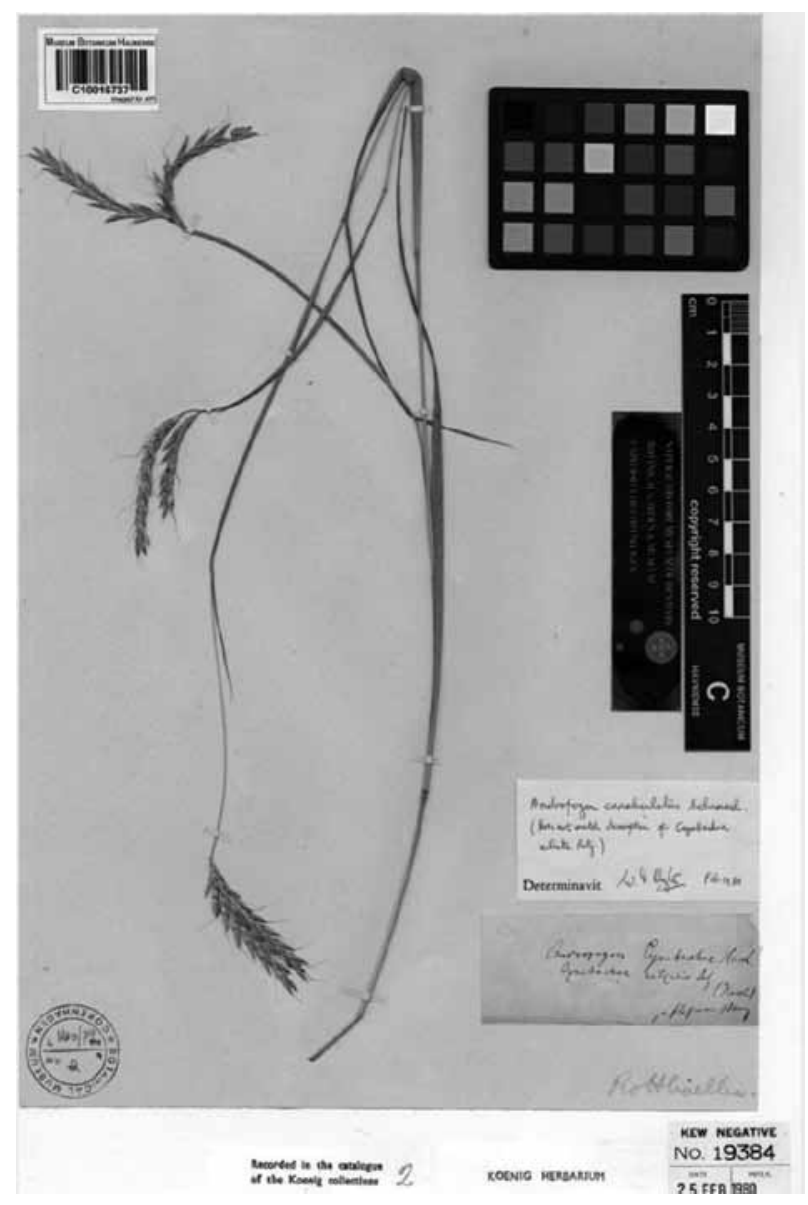

Fig. 4 Sheet C 10016737.

These specimens belong to Andropogon canaliculatus Schumach. This is an African species ranging from Mali to Tanzania and Zimbabwe and never could have been collected by König. Obviously, they were mislabelled and very well could be isotypes of Schumacher's species described from Ghana, the type of which has otherwise not been found as yet. However, the type of $A$. eucnemis Trin. (1832) may very well be an isotype of this, and is here designated as the neotype.

Note that later typifications do not make a name superfluous (ICN Art. 52, Note 2).

Hackel for some reason with a query included Arthrostachys Desv. (1831) with A. gracilis. This was described without prove- 
nance or collector and is immediately distinct by the articulate inflorescence axes. It was not mentioned by Steudel (1854). Clayton \& Renvoize (1986: 349) and Soreng \& Pennington (2003) regarded it as a synonym of Andropogon with which I can agree. Arthrostachya Link (1827) is not an earlier homonym (Art. 53.3.Ex.12).

The undaunted Roberty (1960) not having seen the type, either, nevertheless accepted Cymbachne for 8 Asian and African species with 9 varieties and 72 subvarieties, which others have regarded as taxa belonging to Andropogon (incl. Arthrostachys Desv., Diectomis Kunth, Homoeatherum Nees, and Pollinia Spreng., p.p., Rottboellia auct.).

It may be noted that Palisot de Beauvois (1812: 109, 159) mentioned a "Cymbachne Lour.". This is an error for Stegosia Lour. From the diagnosis and description I have the impression that he had an unawned species of Ischaemum (I. muticum L.?) before him.

Cymbachne Retz. (1791) 36. - Type: Cymbachne ciliata Retz.

Cymbachne ciliata Retz. (1791)36; Roberty (1960) 251 ('ciliaris'). - Rottboellia cymbachne Willd. (1797) 465, nom. superfl. - Cymbachne alata P.Beauv. (1812) 159, nom inval., in syn. - Andropogon cymbachne [Willd.] Hack. (1889) 450, nom. nov., non A. ciliatus Ell. (1816), nec Thunb. (1784a) 903; Thunb. (1784b) 40. - Type: J. König s.n. (LD, not found), Bengal.

$=$ ? Ischaemum muticum $\mathrm{L}$.

\section{Arthrostachys Desv. (1831) 74. - Type: A. gracilis Desv.}

Arthrostachys gracilis Desv. (1831) 74, t. 6, f. 2. - Type: not indicated (?P, P-JU, PC).

= Andropogon $\mathrm{L}$.

Andropogon canaliculatus Schumach. (1827) 52. - Type: not indicated, unknown (expected in $C$, not found, see IDC 2203, Herb. Isert \& Thonning; Hepper 1976: 142), Ghana. Neotype: Thonning s.n. (holo LE), Ghana, designated here.

\section{Andropogon eucnemis Trin. (1832) 275. - Type: Thonning} s.n. in Herb. Trin. 201 ex Herb. Hornemann (holo LE; IDC microfiche BT-16; not in C), Ghana. Possibly homotypic with A. canaliculatus.

Plants perennial. Racemes 2(-3). Internodes of rachis clavate, much wider than the gap between them and the pedicels. Sessile spikelet 4-6 mm long, lower glume not pitted, deeply grooved ('canaliculate'). Pedicelled spikelets well-developed, awnless (briefly mucronate).

Acknowledgements Many people assisted me during this study. Many thanks to Dr. I. Friis (C) for comments on Thonning collections, Mr. P. Frödén (LD), Dr. M.S. Kiran Raj (CALI, Department of Botany, Sree Narayana College, Cherthala - 688 582, Alappuzha, Kerala), Mr. P. Lassen (LD), Mr. P.O. Ryding (C), Dr. M. Sivadasan (KSU), and the institutes that allowed me to study their specimens: A, AMD, BIOT, BISH, BO, BORH, K, KEP, L, MEL, NSW, P, PNH, PTBG, SAN, SAR, SING, SINU, SPN, U, W, WAG.

\section{REFERENCES}

Bailey FM. 1890. Asynopsis of the Queensland flora, Supplement 3: 83. Beal, Brisbane.

Bor NL. 1952 ('1951'). Notes on Dimeria. Kew Bulletin [6]: 455-459.

Bor NL. 1953. Notes on Asiatic grasses XI. The genus Dimeria R.Br. in India \& Burma. Kew Bulletin [7]: 553-592.
Bor NL. 1960. The grasses of Burma, Ceylon, India and Pakistan. Series of Pure and Applied Biology, Botany Division 1: 136-145.

Brown R. 1810. Prodromus florae Novae Hollandiae et insulae Van Diemen 1: 204. Johnson, London.

Buse LH. 1854. Gramineae. In: Miquel FAW, Plantae junghuhnianae 3 (Feb. 1854) preprint: 27; (Aug. 1854) 367. Sythoff, Leiden; Laballière, Paris.

Camus EG, Camus A. 1922. Graminées. In: Lecomte H, Humbert H (eds), Flore Générale de l'Indo-Chine 7: 226-230. Masson, Paris.

Chase A. 1939. Papuan grasses collected by L.J. Brass. II. Journal of the Arnold Arboretum 20: 313.

Chen SL, Phillips SM. 2006. Dimeria. In: Zhengyi W, Raven PH, Hong DY (eds), Flora of China 22: 614-616. Science Press, Beijing, Peoples Republic of China and Missouri Botanical Garden Press, St. Louis, Missouri. Clayton WD, Renvoize SA. 1986. Genera graminum. Grasses of the world. Kew Bulletin, Additional Series 13: 348-349, 376.

Clayton WD, Snow N. 2010. A key to Pacific grasses: 88-89. Kew Publishing, Kew.

Desmond R. 1977. Dictionary of British and Irish botanists and horticulturalists, ed. 3: 675. Taylor \& Franci, Natural History Museum, London.

Desvaux NA. 1831. Opuscules sur les sciences physiques et naturelles. Mémoires de la Société d'Agriculture, Sciences et Arts d'Angers 1: 74, t. 6, f. 2.

Duistermaat H. 2005. Field guide to the grasses of Singapore. Supplement, Gardens Bulletin Singapore 57: 61.

Elliott, S. 1816. A sketch of the botany of South Carolina and Georgia. Schenck, Charleston.

Endlicher S. 1836. Genera plantarum: 106. Beck, Wien.

Estep MC, McKain MR, Diaz DV, et al. 2014. Allopolyploidy, diversification, and the Miocene grassland expansion. PNAS 111, 42: 15149-15154. doi: 10.1073/pnas.1404177111.

Fischer CEC. 1932. The Koenig collection in the Lund herbarium. Bulletin of Miscellaneous Information, Royal Gardens, Kew 1932: 70-75.

Gaudichaud C. 1826. In: De Freycinet L, Voyage autour du monde ... I'Uranie. Botanique: 72, 75. Pillet-Ainé, Paris.

Gaudichaud C. 1829. In: De Freycinet L, Voyage autour du monde ... I'Uranie. Botanique: 412. Pillet-Ainé, Paris.

Gilliland HB. 1971. A revised flora of Malaya. An illustrated systematic account of the Malayan flora, including commonly cultivated plants 3: 213-217. Government Printing Office, Singapore.

Griffith W. 1851a. Notulae ad plantas asiaticas 3: 71. Serrao, Calcutta.

Griffith W. 1851b. Icones plantarum asiaticarum 3: t. 157, f. 2. Government of Bengal, Calcutta.

Hackel E. 1889. Andropogoneae. De Candolle ALPP, De Candolle ACP, Monographiae phanerogamarum, etc. 6: 76-90, 450-451. Masson, Paris. Henty EE. 1969. A manual of the grasses of New Guinea. Botany Bulletin, Lae 1: 80-81.

Hepper FN. 1986. The West African herbaria of Isert \& Thonning: 142. Bentham-Moxon Trust, Royal Botanic Gardens, Kew.

Hitchcock AS. 1936. Botanical results of the Archbold Expedition No. 1. Papuan grasses collected by L.J. Brass. Brittonia 2: 124-126.

Hochstetter CF. 1844. Nova genera plantarum Africae. Flora 27 (1, Bes. Beil.): 6 , t. 4

Honda M. 1930. Monographia Poacearum japonicarum, Bambusoideis exclusis. Journal of the Faculty of Science, University of Tokyo. Section 3, Botany 3: 322-325.

Hooker JD. 1896. Dimeria. In: Hooker JD, Flora of British India 7: 103-106. Reeve \& Co. Ltd.

Hubbard CE. 1934. Gramineae. In: Hutchinson J, The families of flowering plants II. Monocotyledons: 227. Macmillan \& Co., London.

Jansen P. 1953. Notes on Malaysia grasses - I. Reinwardtia 2: 265-267.

Kellogg EA. 2015. Tribes and genera of Panicoideae. In: Kubitzki K, The families and genera of vascular plants 13. Flowering plants. Monocots. Poaceae: 301-302. Springer, Cham, etc.

Kellogg EA, Watson L. 1993. Phylogenetic studies on a large data set. I. Bambusoideae, Andropogonodae, and Pooideae (Gramineae). The Botanical Review 59: 296-297.

Kiran Raj MS. 2008. Taxonomic revision of the subtribe Dimeriinae Hack. of Andropogoneae (Panicoideae-Poaceae) in Peninsular India. Thesis, University of Calicut (partly in L).

Kiran Raj MS, Sivadasan M, Veldkamp JF, et al. 2013a. Nanooravia gen. nov., subtribe Dimeriinae (Poaceae-Panicoideae-Andropogoneae) from India. Nordic Journal of Botany 31: 161-165.

Kiran Raj MS, Sivadasan M, Veldkamp JF, et al. 2013b. Validation of Nanooravia santapaui (Poaceae-Panicoideae-Andropogoneae-Dimeriinae). Nordic Journal of Botany 31: 638.

Kiran Raj MS, Sivadasan M, Veldkamp JF, et al. 2015. A revised infrageneric classification of Dimeria R.Br. (Poaceae-Andropogoneae). Bangladesh Journal of Plant Taxonomy 22: 47-54. 
Koorders SH. 1911. Exkursionsflora von Java 1: 101-102. Fischer, Jena.

Lazarides M. 1980. The tropical grasses of Southeast Asia. Phanerogamarum monographiae 12: 34-35.

Link HF. 1827. Hortus regius botanicus berolinensis 1: 151. Reimer, Berlin.

Merrill ED. 1914. New or noteworthy Philippine plants. Philippine Journal of Science 9: 262-263.

Miquel FAW. 1851. Analecta botanica indica. 2. Gramineae quaedam, praesertim Canaranae. Verhandelingen der Eerste Klasse van het Koninklijk Nederlandsch Instituut van Wetenschappen III, 4: 30-38, reprinted as Analecta Botanica Indica 2: 34-35.

Miquel FAW. 1857. Flora van Nederlandsch Indië 3: 479-480. Van der Post, Amsterdam; Van der Post Jr., Utrecht; Fleischer, Leipzig.

Ohwi J. 1965. Flora of Japan: 187. Smithsonian Institution, Washington.

Palisot de Beauvois AMFJ. 1812. Essai d'une nouvelle Agrostographie: 109, 159, 176. Fain, Paris.

Presl JS. 1830. In: Presl CB, Reliquiae haenkeanae 1: 234-235, 328, t. 38. Calve, Prague.

Reeder JR. 1948. The Gramineae-Panicoideae of New Guinea. Journal of the Arnold Arboretum 29: 324-326.

Rendle A. 1904. In: Forbes FB, Hemsley WB, An enumeration of all the plants known from China proper, etc. Journal of the Linnean Society. Botany 36: 359.

Retzius AJ. 1783. Observationes botanicae 3: 8. Crusium, Leipzig

Retzius AJ. 1791. Observationes botanicae 6: 36-37. Crusium, Leipzig.

Ridley HN. 1891. The grasses and sedges of the Malay Peninsula. Journal of the Straits Branch of the Royal Asiatic Society 23: 27.

Ridley HN. 1903. Turf and fodder grasses. Agricultural Bulletin of the Straits and Federated Malay States 2: 274.

Ridley HN. 1925. The Flora of the Malay Peninsula 5: 191-192. Reeve \& Co. Ltd., London.

Roberty G. 1960. Monographie systématique des Andropogonées du globe. Boissiera 9: 239-257, 396-402.

Schmid M. 1958. Flore agrostologique de l'Indochine. L'Agronomie Tropicale (Nogent-sur-Marne) 13: 149-153.

Schumacher HCF. 1827. Beskrivelse af Guineeiske planter: 52-53. Popps, Copenhagen

\section{INDEX TO SPECIMENS}

chl = Dimeria chloridiformis (Gaudich.) K.Schum. \& Lauterb.

gra $=$ Dimeria gracilis Nees ex Steud.

ker = Dimeria kerrii C.E.Hubb. ex Teerawat. \& Sungkaew (no Malesian material)

Adj. Landbouwc. Pamekasan 7: orn -ANU 2166 (Flenley) chl; 6024 (Wheeler): chl; 28017 (Weatherstone): chl.

Backer 1099: orn; 1928: orn; 2057: orn; 8627: orn; 13886: orn; 16288: orn Bakhuizen v.d. Brink 592: orn; 1594: orn; 2659: orn; 4414: orn; 5346: orn; 6347: orn; 6431: orn; 6446: orn; 6785: orn; 6791: orn; 7965: orn - Barber 309: orn - Bartlett 8342: orn - Beguin B4: orn; C4: orn - Brass 4802: chl; 5911: chl; 5911a (in BO mixed with Eulalia ? trispicata): chl; 5984: orn; 7806 (T): kur; 7807 (T): chl; 7850 : orn; 7932 : chl; 11738 (T): chl - BS 15 (Foxworthy): orn; 1848 (Ramos): orn; 1958 (Williams): orn; 4841 (Ramos): orn; 9320 (Merrill ): chl; 12254 (Foxworthy): orn; 12705 (Loher): orn; 12716 (Loher): orn; 33619 (Ramos \& Edaño): orn; 40525 (Ramos \& Edaño): orn; 41312 (Ramos): orn; 44612 (Ramos \& Edaño): orn; 44628 (Ramos \& Edaño): orn - Burkill 3304: gra.

Chamisso s.n. (LT): orn - Clemens Jul 1907: orn; Feb.-Apr. 1908: orn; 17636: orn; 17655: orn; 20489: orn; 27661: orn; 30316: orn - Co 3034: orn. Duistermaat et al. S 157: orn; S 267: orn.

FB 5293 (Curran): orn; 5294 (Curran): orn; 5822 (Curran): orn; 9960 (Merritt): orn - FMS 22626 (Symington): orn - Forster 56: orn - FRI 63484 (Chew et al.): orn; 63627 (Chew et al.): orn; 63657 (Chew et al.): orn; 70407 (Kiew et al.): orn - Frodin, Morren \& Gabir 2842: chl - Fukuoka \& Ito T-35105: kur. Geerts-Roemer 2: orn - Gilliland 5275: orn - Griffith KD 6799 (T): gra. Holttum Jan. 1945: gra - Hoogland \& Pullen 6053: chl - Miss Hose 20: orn. Iwatsuki et al. S-621: orn.

Jeswiet 770: orn.
Schumann K, Lauterbach K. 1900. Die Flora der deutschen Schutzgebiete in der Südsee: 165. Borntraeger, Leipzig.

Simon BK. 1993. A key to Australian grasses, ed. 2: 103. Queensland Department of Primary Industries, Brisbane.

Soreng RJ, Pennington SJ. 2003. Catalogue of new world grasses (Poaceae): III. Subfamilies Panicoideae, Aristidoideae, Arundinoideae, and Danthonioideae. Contributions from the United States National Herbarium 46: 111.

Sprengel K. 1824. Systema vegetabilium 1: 300. Libraria Dieterichiana, Göttingen.

Stapf O. 1895. Dimeria woodrowii, Stapf. Hooker's Icones plantarum 24: t. 2312.

Stapf O. 1896. Woodrowia diandra, Stapf. Hooker's Icones plantarum 25: t. 2447.

Steudel EG. 1854. Synopsis plantarum glumacearum: 362, 412-413. Metzler, Stuttgart.

Teerawatananon A, Boontia V, Chantarasuwan B, et al. 2014. A taxonomic revision of the genus Dimeria (Poaceae: Panicoideae) in Thailand. Phytotaxa 186: 137-147.

Teerawatananon A, Jacobs SWL, Hodgkinson TR. 2011a. Phylogenetics of Panicoideae (Poaceae) based on chloroplast and nuclear DNA sequences. Telopea 13: 115-142.

Teerawatananon A, Sungkaew S, Hodgkinson TR. 2011b. Arundinella kerrii and Dimeria kerrii, two new endemic species from Thailand (Poaceae, Panicoideae). Novon 21: 149-153.

Thunberg CP. 1784a (May-June). In: Murray JA, Systema vegetabilium, ed. 14: 903. Dieterich, Göttingen.

Thunberg CP. 1784b (Aug.). Flora japonica: 40-41. Müller, Leipzig.

Trimen H. 1885. Notes on the flora of Ceylon. Journal of Botany 23: 272-273.

Trinius CB. 1820. Fundamenta agrostographiae, etc.: 166-167, t. 14. Heubner, Vienna.

Trinius CB. 1832. Andropogineorum genera speciesque complures definitionibus novis. Mémoires de l'Académie Impériale des Sciences de St. Pétersbourg 2: 334-336.

Turczaninov N. 1843. Decas generum plantarum. Bulletin de la Société Imperiale des Naturalistes de Moscou 16: 58. — IDC 7118.

Willdenow CL. 1797. Species plantarum, ed. 4, 1: 465. Nauk, Berlin.

Zollinger H, Moritzi A. 1846. In: Moritzi A, Systematisches Verzeichniss: 99-100. Moritzi, Solothurn.

kur $=$ Dimeria kurzii Hook.f.

orn $=$ Dimeria ornithopoda Trin.

$(\mathrm{LT})=$ Lectotype

$(\mathrm{T})$ = Type

(V) = Voucher: unpublished or invalid names have no types, but 'vouchers'

Kassim 4 Apr. 1959: orn - KEP 63484 (Chew et al.): orn; 63627 (Chew et al.): orn; 63657 (Chew et al.): orn - Kerr 13682: kur; 13868 (T): ker; 20132 : kur - Kjellberg 715: orn - KLU 8157 (Kassim \& Carrick): gra - Kneucker Exsicc. 781 (Merrill): orn - Kooper 10 Sept. 1932: orn - Koorders 40179: orn; 41071: orn; 41079: orn.

LAE 60770 (Croft et al.): chl - Lazarides 7457: kur; 7474: kur - Loher 1856: orn; 7214: orn.

McDonald \& Ismail 4179: orn - Merrill 360: orn; 3226 (V): orn; 3283: orn; 3286: sp.; 3676: orn; 3773: orn; 9320 (T): chl - Monod de Froideville 923: orn; 1776: orn; 1859: orn; 1902: orn - Motley 451: orn.

NGF 34700 (Croft \& Lelean): chl.

PNH 35799 (Blanco): orn - Powell 6024: chl - Pullen 7206: orn; 7250: chl - Putek 21: orn.

Ramos 1123: orn; 1301: orn - Ridley 27 Mar. 1889: orn; 79: orn; 1703: orn; 10013: orn; 11718: orn; 11961: orn; 12140: orn; 14880: chl - Robbins 377: chl.

Santos 4020: orn; 4642: orn; 5883: orn; 6095: orn; 7379: orn; 7380: orn; 7395: kur; 7431: orn - Schmutz 6687: orn - SF 2961 (Haniff \& Nur): kur; 4522 (Nur): orn; 4622 (Burkill): orn; 4674 (Burkill) (T): orn; 4756 (Nur): orn; 4786 (Nur): orn; 24681 (Holttum): orn; 37335 (Spare): orn; 37753 (Corner): orn; 67753 (Corner): orn; 154508 (Haniff): orn - Sørensen et al. 136: kur. Teruya 2076: orn; 2138: orn.

Van der Veen 14: orn - Van Steenis 7892: orn - Veldkamp \& Nurainas 2357: orn - Verheijen 427: orn - Vesterdal 181: gra; 577: orn.

White 2: orn - Widjaja \& Hamzah 2911: chl - Winckel 1477: orn.

Yacob 16: kur.

Zollinger $351(\mathrm{~T})$ : orn; $1595(\mathrm{~T})$ : orn. 